\title{
Factors influencing the distribution and activity of Dermacentor reticulatus (F.) ticks in an anthropopressure-unaffected area in central-eastern Poland
}

\author{
Zbigniew Zając', Katarzyna Bartosik', Alicja Buczek \\ ${ }^{1}$ Chair and Department of Biology and Parasitology, Medical University, Lublin, Poland \\ Zając Z, Bartosik K, Buczek A. Factors influencing the distribution and activity of Dermacentor reticulatus (F.) ticks in an anthropopressure- \\ unaffected area in central-eastern Poland. Ann Agric Environ Med. 2016; 23(2): 270-275. doi: 10.5604/12321966.1203889
}

\begin{abstract}
Introduction and objectives. Despite the increasing prevalence and significant role of $D$. reticulatus in pathogen transmission, the factors influencing its distribution and activity are still poorly known. The paper presents for the first time a study of the $D$. reticulatus ecology in a protected area, in which the dependence of $D$. reticulatus occurrence and activity on the ecological habitat type is analysed.

Materials and methods. Tick collection and environmental monitoring were conducted from March - November 2012 and 2014 in five ecologically-diverse habitats in the Polesie National Park of central-eastern Poland.

Results. The study shows that the most beneficial habitats for $D$. reticulatus are provided by meadow ecosystems dominated by plants from the class Molinio-Arrhenatheretea: Poa pratensis, P. trivialis, Festuca rubra, F. pratensis, and Alopecurcus pratensis, as well as Carex sp. sedges ( $64.78 \%$ of the tick collections). Less favourable conditions are offered by the fresh habitat covered by deciduous forest with dominance of Betula sp., A. pratensis, and Carex sp. sedges (15.27\%), in the wet habitat dominated by Alnus glutinosa and Urtica dioica (9.00\%), Betula humilis, Salix sp., and Carex sp. (8.44\%), and in the subcontinental hornbeam forest Tilio-Carpinetum with poor undergrowth (2.50\%). D. reticulatus avoids wet habitats with bog birch Betuletum pubescientis communities and moist pine forest Molinio-Pineteum, as well as habitats dominated by heather Calluna vulgaris.

Conclusions. The distribution and dynamics of the activity of adult $D$. reticulatus depends on the biological and geoclimatic conditions prevailing in tick habitats. The structure of the flora colonising a habitat may be an indicator of the presence of this tick species.
\end{abstract}

\section{Key words}

Dermacentor reticulatus, activity, abundance, habitat preferences, protected area

\section{INTRODUCTION}

The geographical range of Dermacentor reticulatus covers a vast area in Eurasia. Over the last 10 years, expansion of this tick species into new habitats has been reported [1]. The abundance of $D$. reticulatus population has also been increasing [2]. The extension of the occurrence range and increased quantity of $D$. reticulatus raises the risk of animal and human health infections with tick-borne pathogens transmitted by the tick species, e.g. protozoa from the genus Babesia $[3,4]$, tick-borne encephalitis viruses $[5,6]$ rickettsiae [7], and other bacteria [8]. Therefore, identification of factors that influence $D$. reticulatus distribution and activity is fundamental for epidemiological investigations of tick-borne diseases in Europe.

Particularly interesting are observations carried out in protected areas where natural environmental conditions are conserved, since they allow determination of the habitat preferences of $D$. reticulatus. Moreover, comparison of results of field studies conducted in habitats affected by anthropopressure with those obtained in legally protected areas, can indicate the extent to which human activity influences the spread of this tick species, and the growing threat to animal and human health posed by tick attacks.

Address for correspondence: Alicja Buczek, Chair and Department of Biology and Parasitology, Radziwiłłowska 11, Medical University, 20-080 Lublin, Poland E-mail: alicja.buczek@umlub.pl

Received: 18 December 2015; accepted: 17 February 2016
The study was undertaken in the Polesie National Park in central-eastern Poland, which is situated within the occurrence range of the eastern $D$. reticulatus population, and is simultaneously unaffected by anthropopressure. The research was focused on investigation of the impact of habitat type on the distribution and the-host seeking behaviour of this tick species.

\section{MATERIALS AND METHOD}

Study area. The Polesie National Park (PNP) with an area of $97.6 \mathrm{~km}^{2}$ is located in lowland areas of central-eastern Poland $\left(51^{\circ} 27^{\prime} \mathrm{N} 23^{\circ} 10^{\prime} \mathrm{E}\right)$ (Fig. 1) in a zone with temperate climate

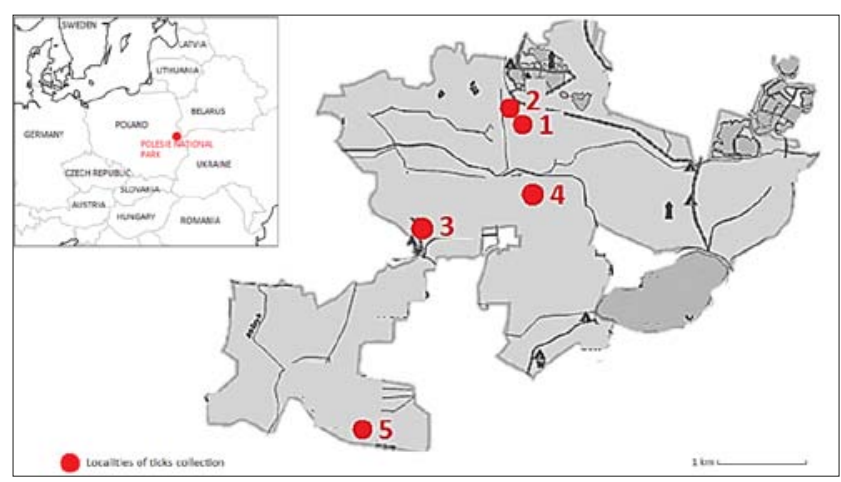

Figure 1. Location of $D$. reticulatus tick habitats in the Polesie National Park 
and continental features. The mean annual temperature in the area is $7.4^{\circ} \mathrm{C}$, with relatively high mean air temperatures in summer and low values in winter; this makes the annual temperature amplitude one of the highest in Poland. The mean annual precipitation figures in this area are $542 \mathrm{~mm}$ and represent the lowest values in eastern and central Europe. In autumn, precipitation levels exceed those noted in spring. The mean relative air humidity is $67 \%$ [9].

Forest communities with the largest cover in the PNP are represented by continental mixed coniferous forest Querco roboris-Pinetum (30\%), mixed alder fen forest Sphagno squarrosi-Pinetum (26\%), sub-continental hornbeam forest Tilio-Carpinetum (25\%), bog birch forest Betuletum pubescentis (23\%), and black alder forest Ribo nigri-Alnetum (15\%). Non-forest ecosystems are represented by aquatic-bog habitats that are unique in Europe, i.e. carbonate peat bogs with Molinia meadow communities, and transitional mire vegetation. A large area is covered by meadows dominated by Poa pratensis-Festuca rubra communities. The area is inhabited by 48 species of mammals, with rodents as the most numerous group [10].

Study localities. The investigations were carried out for two years in ecologically different habitats: in 2012, in five localities (localities 1-5), and in 2014, in only four localities due to the persisting high level of ground waters in one locality (Locality 5), which prevented tick collection. An inventory of vascular plants was made in each locality. The species were identified using the key developed by Szafer et al. [11], and dominant plant communities recognised [12].

\section{Figure 2A. Locality 1.}

The transect along which ticks were collected, extended across meadows with heath enclaves, Betula sp. groups, and single Pinus sylvestris specimens. It was dominated by meadow vegetation from the class Molinio-Arrhenatheretea, as well as the community Poa pratensis-Festuca rubra with substantial cover of Poa pratensis, P. trivialis, Festuca rubra, F. pratensis, Alopecurcus pratensis, Holcus lanatus, and Phleum pratense growing on slightly acidic, often calcareous, peat substrates. This is fresh vegetation which can also colonise drier areas. This habitat also comprised patches of vegetation from the community Sieglingio-Agrostietum, characterised by a high share of Calluna vulgaris heather, as well as grostis capillaris. This habitat type exhibits a moderate moisture level. The banks of the lakes were colonised by vegetation from the sedge rush association Caricetum paniculata and the fen sedge association Cladietum marisci, characteristic for fresh and moist habitats.

\section{Figure 2B. Locality 2.}

The transect was situated along a mid-forest path and a tract between two water reservoirs. The tree stand in this locality was dominated by birch Betula sp., Alnus glutinosa, Salix sp. and species characteristic for the sub-continental hornbeam forest Tilio-Carpinetum, as well as shrubs, primarily deciduous tree saplings. The most frequent grass species included $A$. pratensis and Carex sp.sedges. A part of the path was a mid-forest clearing with a considerable share of plants characteristic for the class Molinio-Arrhenatheretea and the community Poa pratensis-Festuca rubra. Areas near the water reservoirs were overgrown by low grass species. The locality had the character of a fresh and moist habitat.
Figure 2C. Locality 3 .

The transect extended across a forest and along the bank of Lake Moszne. The first section mentioned was dominated by deciduous forests - sub-continental hornbeam forest TilioCarpinetum (low and typical hornbeam forest) with single coniferous specimens. The understorey and groundcover were poor. The area located closer to the lake was dominated by the moist pine forest Molinio-Pineteum. The area was also covered by a hummock-hollow alder forest. The lake banks were dominated by the bog birch forest Betuletum pubescentis, as well as birch Betula humilis scrubsand Salix sp. shrubs.

\section{Figure 2D. Locality 4.}

The locality was situated in a moist habitat. On one side, it bordered a watercourse and on another side it was adjacent to wet areas covered by forests. Ribeso nigri-Alnetum was the dominant plant community. This type of vegetation community was characterised by dominance of Alnus glutinosa and the so-called hummock-hollow structure with hollows filled with water. The elevated part of the area was colonised by birch $B$. humilis, willow Salix sp., elongated sedge Carex elongata, crested wood-fern Dryopteris cristata, black currant Ribes nigrum, and peat moss Sphagnum sp. Additionally, wild shrubs of raspberry Rubus sp., dog-rose Rosa canina, and common nettle Urtica dioica were found in this locality.

\section{Figure 2E. Locality 5 .}

There were two distinct ecological habitat types in this locality. In one of the sections of the transect, there was a moist habitat dominated by the community Ribeso nigriAlnetum with a substantial share of $A$. glutinosa and single specimens of Betula humilis and willow Salix sp. A great number of Carex sedge species and $U$. dioica were also noted. A fresh habitat constituted the other part of the transect, i.e. a midforest clearing delineated by a watercourse on one side and a forest on the other, covered by grasses, and a Sphagnetum magellanicipeat bog with single specimens of Betula sp. and $P$. sylvestris.

The transects from which ticks were collected for the presented study coincided with the didactic-ecological path, i.e. a popular recreational site for the residents of the Lublin Province and tourists from all over Europe. The locality is frequently visited by Polish schoolchildren for field biology classes.

Tick collection. The flagging method was used for the collection of unfed $D$. reticulatus adults. After sweeping a several-meter long fragment of vegetation with a flannel cloth, the flag was viewed, attached specimens collected and placed in transport containers. Throughout the observation period, the plants were always swept by the same person in all localities. Each time, ticks were collected for one hour. In the laboratory, the specimens in each sample were counted and the tick species and gender identified.

The field study was conducted at ca. 14-day intervals throughout the vegetation period for this part of Poland, i.e. from mid-March - mid-November. During the longer daylight hours, between May and mid-September, the field study was carried out twice a day. In turn, during the shorter daylight hours in autumn, the ticks were collected once a day. The choice of the time of tick collection followed 

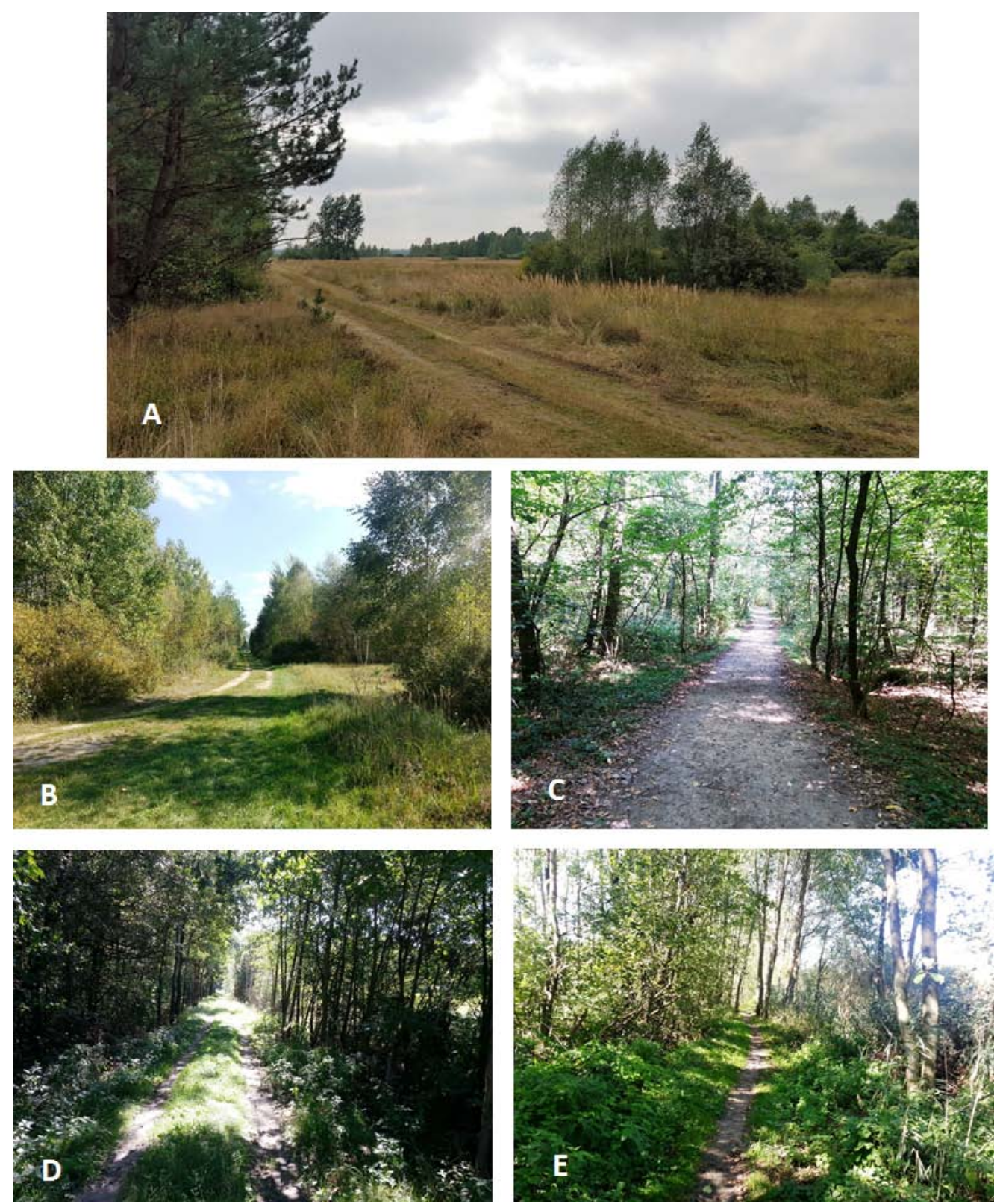

Figure 2. Ecologically different habitats of Dermacentor reticulatus located in the Polesie National Park: A- locality 1; B - locality 2 ; C - locality 3; D - locality 4; E - locality 5.

previous studies [13]. Ticks were usually collected only on clear days without precipitation and with moderate or no wind.

During each collection round, air temperature and humidity were measured using electronic devices. The temperature and humidity of the air were measured at three levels, i.e. at ground level $(0 \mathrm{~cm})$, at the mean height of plants growing at the collection site $(30 \mathrm{~cm})$, and at a height of $70 \mathrm{~cm}$ above the ground. At the time of analysis of the results, the measurement data were averaged. Information about the length of daylight on the tick collection days was obtained from a database [14].

The study was conducted with Permission No. 7/2012, 6/2013, 3/2014 of the Directorate of the PNP.

Statistical analysis. Differences between two groups were analysed with the Mann-Whitney U test. In the case of more than two groups, the comparison was based on the chi-square
Kruskal-Wallis test. A significance level of $\mathrm{p}=0.05$ was assumed.

\section{RESULTS}

Distribution and abundance of $D$. reticulatus in various habitats. During the two-year field study conducted in the PNP, a total of 4,276 D. reticulatus specimens were collected: 2,436 females and 1,840 males (Tab. 1). The greatest number of specimens (64.79\%) was collected in the open ecosystem covered by meadow plants from the class Molinio-Arrhenatheretea, community Poa pratensisFestuca rubra, bordering the mixed forest and watercourses (Locality 1). A four-fold lower number of ticks (15.27\%) than that in Locality 1 was noted for the mid-forest paths in forests dominated by deciduous trees in Locality 2 . Adult D. reticulatus stages were also abundant in Locality 5 , where 
Table 1. Number of adult $D$. reticulatus stages collected in the different localities in the Polesie National Park in the period of tick seasonal activity in 2012 and 2014

\begin{tabular}{lcccccc}
\hline \multirow{2}{*}{ Locality } & \multicolumn{2}{c}{$\begin{array}{c}\text { Range of temperature } \\
(\mathrm{T}) \text { and humidity }(\mathrm{H})\end{array}$} & \multicolumn{5}{c}{$\begin{array}{c}\text { Number } \\
\text { of collected ticks }\end{array}$} \\
\cline { 2 - 7 } & $\mathrm{T}\left[{ }^{\circ} \mathrm{C}\right]$ & $\mathrm{H}[\%]$ & Females $(\mathrm{F})$ & Males $(\mathrm{M})$ & Total & Ratio F:M \\
\hline 1 & $9.1-34.6$ & $33.4-80.2$ & 1,519 & 1,251 &, & 1.21 \\
\hline 2 & $11.0-31.1$ & $32.4-82.6$ & 390 & 263 & 653 & 1.48 \\
\hline 3 & $11.8-32.6$ & $41.5-88.3$ & 75 & 32 & 107 & 2.34 \\
\hline 4 & $9.7-33.2$ & $32.1-82.7$ & 225 & 160 & 385 & 1.40 \\
\hline 5 & $14.0-28.2$ & $50.9-82.9$ & 227 & 134 & 361 & 1.69 \\
\hline Study area & $\mathbf{9 . 1 - 3 4 . 6}$ & $\mathbf{3 2 . 1 - 8 8 . 3}$ & $\mathbf{2 , 4 3 6}$ & $\mathbf{1 , 8 4 0}$ & $\mathbf{4 , 2 7 6}$ & $\mathbf{1 . 3 3}$ \\
\hline
\end{tabular}

$8.44 \%$ of all specimens collected during a two-fold shorter time (one-year investigations in 2012). A bigger number of adult ticks was found in the fresh habitat dominated by plants from the class Molinio-Arrhenatheretea. In the other localities (3 and 4), the tick abundance was substantially lower and reached $2.5 \%$ and $9.0 \%$, respectively, of all specimens collected during the study (Tab. 1).

The statistical test confirmed the differences in tick abundance in the different habitats during the two study years. No statistically significant difference was demonstrated between the number of active ticks in 2012 and 2014, neither in the entire study area $(\mathrm{Z}=-0.268 ; \mathrm{p}=0.789)$ nor in each analysed locality (Locality $1: Z=0.190 ; p=-0.849$; Locality 2 : $\mathrm{Z}=-0.199 ; \mathrm{p}=0.842$; Locality $3: \mathrm{Z}=-0.024 ; \mathrm{p}=0.842$; Locality $4: \mathrm{Z}=-1.627 ; \mathrm{p}=0.104)$.

The proportions of females and males differed between the localities. The greatest differences in the number of specimens of both genders were revealed in Locality 3 , where the number of females was 2.34-fold higher than that of male specimens. In the other localities, the dominance of females over males was nearly two-fold lower. As shown by the study, similar temperature and humidity conditions prevailed during the collection of $D$. reticulatus in all the tick habitats (Tab. 1).
Seasonal activity of $D$. reticulatus. A bimodal rhythm of the seasonal activity of adult $D$. reticulatus ticks was demonstrated in both study years in all the investigated localities. The spring activity began in March and exhibited a peak in May when, on average, 20.90 females and 15.02 males were collected per hour in the two-year study period. Males were found to be more active in March and the first half of April, whereas females dominated over males from late May to late June (Tab. 2).

The second activity peak in the analysed area began in mid-August (Tab. 2). From the beginning of September, the activity of the adult stages increased nearly 12 -fold in comparison to August. The peak of autumn activity was noted at the turn of October - November. Active females dominated over males from early October to the end of autumn $D$. reticulatus activity.

A similar rhythm of the seasonal activity of adult D. reticulatus was noted in both study years (Tab. 2). The statistical test confirmed statistically significant differences in the activity of adult $D$. reticulatus in spring and autumn in the entire study area, in both 2012 and 2014 ( $\mathrm{p}=0.007$; $\mathrm{Z}=-2.676)$.

Within the investigated habitats, statistically significant differences between the spring and autumn activities were only noted in Locality 1 in $2012(\mathrm{Z}=-2.148 ; \mathrm{p}=0.032)$ and in Locality 2 in $2014(\mathrm{Z}=-2.344 ; \mathrm{p}=0.019)$.

In the Polesie National Park, ticks were active at a temperature ranging from $9.1-34.6^{\circ} \mathrm{C}$ (mean temperature: $22.9 \pm 5.57^{\circ} \mathrm{C}$ ) and air humidity - 31.10-88.30\% (mean humidity: 59.92\% \pm 11.28 ) (Tab. 1). Statistical analysis performed for the entire study area showed that air temperature had a significant effect on the activity of adult $D$. reticulatus ticks $\left(\chi^{2}=28.386 ; \mathrm{p}<0.001\right)$. However, no correlations were found between the number of collected ticks and air humidity in the entire protected area $\left(\chi^{2}=7.134 ; \mathrm{p}=0.068\right)$ and in the phytosociologically different localities (Locality $1: \chi^{2}=4.690 ; p=0.196$; Locality $2: \chi^{2}=1.632$; $\mathrm{p}=0.652$; Locality $3: \chi^{2}=6.377 ; \mathrm{p}=0.095$; Locality $4: \chi^{2}=2.864$; $\mathrm{p}=0.413$; Locality $\left.5: \chi^{2}=0.513 ; \mathrm{p}=0.774\right)$.

Table 2. Seasonal activity of adult D. reticulatus stages at the different localities in the Polesie National Park in 2012 and 2014.

\begin{tabular}{|c|c|c|c|c|c|c|c|c|c|c|}
\hline \multirow{3}{*}{ Month and year } & \multicolumn{10}{|c|}{ Locality/Average number of ticks collected by 1 person during 1 hour } \\
\hline & \multicolumn{2}{|c|}{1} & \multicolumn{2}{|c|}{2} & \multicolumn{2}{|c|}{3} & \multicolumn{2}{|c|}{4} & \multicolumn{2}{|c|}{5} \\
\hline & $F$ & $M$ & $F$ & $M$ & $F$ & M & $F$ & M & $F$ & M \\
\hline April 2012 & nd & nd & nd & nd & 7.00 & 1.00 & nd & nd & 42.00 & 11.75 \\
\hline April 2014 & 26.00 & 27.30 & 8.00 & 8.30 & nd & nd & 6.33 & 8.00 & nd & nd \\
\hline May 2012 & 59.75 & 25.50 & 41.00 & 12.50 & 8.00 & 1.00 & 16.25 & 7.00 & 22.00 & 7.00 \\
\hline May 2014 & 40.50 & 59.50 & 10.50 & 10.10 & 3.66 & 2.33 & 2.50 & 2.75 & nd & nd \\
\hline June 2012 & 5.80 & 3.00 & 3.80 & 4.70 & 1.50 & 0.25 & 6.25 & 1.25 & 1.50 & 1.00 \\
\hline June 2014 & 6.00 & 3.00 & 2.00 & 3.00 & 0.00 & 3.00 & 0.00 & 0.00 & nd & $\mathrm{Nd}$ \\
\hline July 2012 & nd & nd & 0.00 & 0.00 & 4.00 & 0.00 & 0.00 & 0.00 & 0.00 & 0.00 \\
\hline July 2014 & 0.00 & 0.00 & 0.00 & 0.00 & 0.00 & 0.00 & 0.00 & 0.00 & nd & nd \\
\hline August 212 & 0.00 & 0.00 & 0.00 & 2.00 & 0.00 & 0.00 & 0.00 & 0.00 & 0.00 & 0.00 \\
\hline August 2014 & nd & nd & 4.00 & 6.00 & 0.00 & 0.00 & nd & nd & nd & nd \\
\hline September 2012 & 67.75 & 34.00 & 16.50 & 10.50 & 2.00 & 0.25 & 20.50 & 15.75 & 21.75 & 18.50 \\
\hline September 2014 & 24.67 & 33.67 & 12.50 & 8.20 & 6.00 & 3.00 & 0.50 & 2.50 & nd & nd \\
\hline October 2012 & 121.00 & 82.00 & 11.50 & 9.00 & 5.00 & 7.00 & 13.00 & 8.00 & 22.00 & 11.00 \\
\hline October 2014 & 131.00 & 75.00 & 12.50 & 20.00 & 0.00 & 2.00 & 3.00 & 2.00 & nd & nd \\
\hline November 2012 & 96.50 & 83.50 & nd & nd & nd & nd & nd & nd & nd & nd \\
\hline November 2014 & 100.00 & 80.00 & nd & nd & nd & nd & 0.00 & 4.00 & nd & nd \\
\hline
\end{tabular}

F-females; M - males; nd - no data 
Comparison of the study results obtained in the different habitats indicates a statistically significant correlation between temperature and the number of active ticks only in Locality $1\left(\chi^{2}=12.887 ; \mathrm{p}=0.002\right)$, but not in others (locality 2 $\chi^{2}=4.841 ; \mathrm{p}=0.089 ;$ locality $3 \chi^{2}=0.415 ; \mathrm{p}=0.813$; locality 4 : $\chi^{2}=5.122 ; \mathrm{p}=0.077$; locality: $\left.5 \chi^{2}=0.356 ; \mathrm{p}=0.837\right)$.

The greatest number of specimens was collected in a period with less than 11 hours of daylight (i.e. October and November); in turn, the lowest number of ticks was found on days with more than 15 hours of daylight (i.e. June, July and August). The statistical test confirmed the correlation between the length of daylight and activity of $D$. reticulatus $\left(\chi^{2}=45.027 ; \mathrm{p}<0.001\right)$.

\section{DISCUSSION}

Results of field studies on the distribution, abundance, and activity of $D$. reticulatus in environments characterised by varied degrees of anthropopressure in various geographical regions, have so far been analysed primarily with reference to selected climatic indicators noted during the study periods, i.e. mainly temperature and humidity $[2,13,15,16,17,18]$, some habitat traits $[17,19,20,21]$, or in terms of the host species composition $[22,23]$.

As indicated in this study, in a protected area, distribution, abundance, and activity of D. reticulatus depend on the type of habitat, which is defined by characteristic plant groups determined by the climate and soil conditions, and presence of specific animal species. Meadow ecosystems with fresh vegetation bordering forested areas and watercourses offer the most favourable conditions for $D$. reticulatus development in anthropopressure-unaffected areas. Such habitats ensure the frequent presence of many animals that can be hosts for immature tick stages $[19,24,25,26,27]$ and adult ticks $[28,29,30]$.

In the area of the PNP, the accumulation of adult $D$. reticulatus ticks was observed on meadow vegetation from the class Molinio-Arrhenatheretea, which serves as food for such animals as the elk (A. alces), deer (C. elaphus), wild boar (S. scrofa), and, to a lesser extent, roe deer (C. capreolus) $[31,32,33]$. An inventory made in two hunting districts and comprising the presented study area, revealed the presence of numerous animals (Tab. 3) regarded as the

Table 3. Occurrence of hosts of adult $D$. reticulatus stages in the study area, habitat and feeding preferences

\begin{tabular}{|c|c|c|c|}
\hline Species & $\begin{array}{c}\text { No. of } \\
\text { individuals }\end{array}$ & Habitat preferences & Feeding preferences \\
\hline $\begin{array}{l}\text { Elk } \\
\text { Alces alces }\end{array}$ & $\begin{array}{c}150^{1} \\
1,543^{2}\end{array}$ & $\begin{array}{l}\text { Open meadows, banks of } \\
\text { water bodies and rivers }\end{array}$ & $\begin{array}{l}\text { Herbaceous plants, aquatic } \\
\text { plants, grasses, sedges }\end{array}$ \\
\hline $\begin{array}{l}\text { Deer } \\
\text { Cervus } \\
\text { elaphus }\end{array}$ & $\begin{array}{c}100^{1} \\
4,040^{2}\end{array}$ & $\begin{array}{l}\text { Meadows, deciduous and } \\
\text { mixed forests }\end{array}$ & $\begin{array}{l}\text { Shoots, leaves, and bark of } \\
\text { trees and shrubs, grasses }\end{array}$ \\
\hline $\begin{array}{l}\text { Wild boar } \\
\text { Sus scrofa }\end{array}$ & $\begin{array}{c}200^{1} \\
8,798^{2}\end{array}$ & $\begin{array}{l}\text { Deciduous and mixed } \\
\text { forests with beech and } \\
\text { oak, riparian forests, bogs, } \\
\text { and meadows }\end{array}$ & $\begin{array}{l}\text { Omnivorous species; mainly } \\
\text { acorns, plant rhizomes, } \\
\text { grasses, tubers }\end{array}$ \\
\hline $\begin{array}{l}\text { Roe deer } \\
\text { Capreolus } \\
\text { capreolus }\end{array}$ & $\begin{array}{c}600^{1} \\
21,465^{2}\end{array}$ & $\begin{array}{l}\text { Deciduous and mixed } \\
\text { forests, scrubs, meadows }\end{array}$ & $\begin{array}{l}\text { Shoots, leaves, and bark of } \\
\text { trees and shrubs, grasses }\end{array}$ \\
\hline
\end{tabular}

${ }^{1}$ No. of individuals in the Polesie National Park (area of $97.6 \mathrm{~km}^{2}$ ) [19].

${ }^{2}$ No.of individuals in the Biała Podlaska (area: $5,348 \mathrm{~km}^{2}$ ) and Chełm (area: $3,866 \mathrm{~km}^{2}$ ) Hunting Districts comprising the Polesie National Park [53]. major D. reticulatus hosts in Europe. These animals do not exhibit territorial behaviour; therefore, they can be assumed to migrate in search of food to the habitats situated in the analysed protected area.

Meadow ecosystems adjacent to forests offer favourable temperature and humidity conditions required for maintenance of water balance, which is indispensable for the survival and development of the immature and adult stages of D. reticulatus $[17,18]$. Temperature and humidity conditions prevailing in meadow ecosystems satisfy $D$. reticulatus preferences defined in laboratory studies.

In the protected areas in eastern Poland, no D. reticulatus ticks were found in the habitats of the moist pine forest Molinio-Pineteum, bog birch forest Betuletum pubescentis, and in transect sections covered by heather (C. vulgaris).

The current study shows not only a considerable abundance of $D$. reticulatus populations, but also the greatest numbers of adult specimens during the autumn activity peak in the meadow ecosystem bordering the forest complexes. For this type of habitat, a statistically significant correlation was found between the $D$. reticulatus activity and temperature, which was not reported from the other habitats.

The absence of a statistically significant correlation between the number of active ticks and temperature in the localities situated on the mid-forest paths (Locality 2 and 4), in the deciduous forest (Locality 3), and in the clearing partly covered by alder forest (Locality 5 ), may be caused by the more stable abiotic conditions offered by these habitats in the different seasons of the year, compared with open areas. Both during the morning and afternoon collection sessions, greater temperature fluctuations were observed in the meadow ecosystems than in the other localities.

The abundance of $D$. reticulatus ticks in the protected area in central-eastern Poland is substantially higher than that in anthropopressure-affected regions in other parts of the Lublin macroregion [26, unpublished data]. The differences in the methodologies employed in this study, and in investigations carried out by other researchers in different parts of Europe, make it impossible to compare their results and determine the impact of anthropogenic factors on $D$. reticulates populations. In other tick species originating from contaminated regions, differences were noted in their abundance and seasonal activity rhythm in areas with a varied degree of anthropopressure [34,35,36], as well as developmental distortions leading to morphological anomalies in many specimens $[37,38]$.

The dominance of active females over males reported from the shady areas of the deciduous moist sub-continental hornbeam forests (locality 3), compared with their numbers in the open areas of the moderately moist meadows (Locality 1) noted during the presented study, can be explained by the differences in the morphology (degree of chitinisation of the body surface) and physiology between the two genders, and their different temperature and humidity requirements. Since they are exposed to higher risk of water loss, females reduce their activity in adverse conditions. In an earlier study by the authors conducted in various types of habitats in eastern Poland, it was found that females and males exhibited the highest activity at a temperature of $20^{\circ} \mathrm{C}$ and $65 \%$, and $18{ }^{\circ} \mathrm{C}$ and $60 \%$ humidity, respectively (Buczek et al. unpublished data).

The presented and previous results $[2,13,17,18]$ of studies conducted in eastern Poland, and those reported by other 
authors $[15,16,20,39]$, confirm the bimodal rhythm of the activity of adult $D$. reticulatus ticks, irrespective of the habitat type and climatic conditions. In turn, they indicate dependence of the dynamics of the activity of adult stages of this species on climatic and weather [18] conditions. The current study was carried out in the same period and in different habitats of the protected area and indicates the impact of the habitat type on the activity of adult D. reticulatus ticks in different seasons of the year.

The wide range of temperature and humidity tolerance, as well as the habitat requirements of $D$. reticulatus determined in this study, may explain the expansion of the species into new areas [40], including recreational suburban areas $[41,42]$.

\section{Acknowledgments}

The authors wish to thank M.Eng. Jarosław Szymański and D.Eng. Szymon Kolasa from the Directorate of the Polesie National Park, for the help in conducting these investigations.

\section{REFERENCES}

1. Rubel F, Brugger K, Pfeffer M, Chitimia-Dobler L, Didyk YM, Leverenz S, Dautel H, Kahl O. Geographical distribution of Dermacentor marginatus and Dermacentor reticulatus in Europe. Ticks Tick Borne Dis. 2016; 7(1): 224-33 doi: 10.1016/j.ttbdis.2015.10.015.

2. Buczek A, Bartosik K, Wiśniowski L, Tomasiewicz K. Changes in population abundance of adult Dermacentor reticulatus (Acari: Amblyommidae) in long-term investigations in eastern Poland. Ann Agric Environ Med. 2013; 20(2):269-272.

3. Rar VA, Maksimova TG, Zakharenko LP, Bolykhina SA, Dobrotvorsky AK, Morozova OV. Babesia DNA detection in canine blood and Dermacentor reticulatus ticks in southwestern Siberia, Russia. Vector Borne Zoonotic Dis. 2005; 5(3): 285-287.

4. Wójcik-Fatla A, Bartosik K, Buczek A, Dutkiewicz J. Babesia microti in adult Dermacentor reticulatus ticks from eastern Poland. Vector Borne Zoonotic Dis. 2012; 12(10): 841-843.

5. Wójcik-Fatla A, Cisak E, Zając V, Zwoliński J, Dutkiewicz J. Prevalence of tick-borne encephalitis virus in Ixodes ricinus and Dermacentor reticulatus ticks collected from the Lublin region (eastern Poland). Ticks Tick Borne Dis. 2011; 2(1): 16-19.

6. Biernat B, Karbowiak G, Werszko J, Stańczak J. Prevalence of tickborne encephalitis virus (TBEV) RNA in Dermacentor reticulatus ticks from natural and urban environment, Poland. Expl App Acarol. 2014; 64(4): 543-551.

7. Stańczak J. Detection of spotted fever group (SFG) rickettsiae in Dermacentor reticulatus (Acari: Ixodidae) in Poland. Int J Med Microbiol. 2006; 296(S40): 144-148.

8. Hubálek Z, Sixl W, Halouzka J, Mikulaskova M. Prevalence of Francisella tularensis in Dermacentor reticulatus ticks collected in adjacent areas of the Czech and Austrian Republics. Cent Eur J Public Health. 1997; 5(4): 199-201.

9. Radwan S. Polesie National Park. Morpol, 2002 (in Polish).

10. http://www.poleskipn.pl. (accessed 20 August 2015)

11. Szafer W. Polish plants: descriptions and keys for identification of all vascular plant species growing in Poland. Part. 1 and 2. PWN, 1972 (in Polish).

12. Matuszkiewicz W. Guidebook of identification of plant communities in Poland. PWN, 2006 (in Polish)

13. Bartosik K, Wiśniowski L, Buczek A. Questing behavior of Dermacentor reticulatus adults (Acari: Amblyommidae) during diurnal activity periods in eastern Poland. J Med Entomol. 2012; 49(4): 859-864.

14. http:// www.kalendarz-365.pl. Accessed 20 August 2015.

15. Martinod S, Gilot B. Epidemiology of canine babesiosis in relation to the activity of Dermacentor reticulatus in southern Jura (France). Exp Appl Acarol. 1991; 11(2-3): 215-222.

16. Razumova IV. Aktivnost' kleshchej Dermacentor reticulatus Fabr. (Ixodidae) v prirode. Med Parazitol (Mosk). 1998; 4:8-14 (in Russian).

17. Bartosik K, Wiśniowski L, Buczek A. Abundance and seasonal activity of adult Dermacentor reticulatus (Acari: Amblyommidae) in eastern Poland in relation to meteorological conditions and the photoperiod. Ann Agric Environ Med. 2011; 18(2): 340-344.
18. Buczek A, Bartosik K, Zając Z. Changes in the activity of adult stages of Dermacentor reticulatus (Ixodida: Amblyommidae) induced by weather factors in eastern Poland. Parasit Vectors. 2014; 7: 245.

19. Nosek J. The ecology and public health importance of Dermacentor marginatus and D. reticulatus ticks in Central Europe. Folia Parasitol. 1972; 19(1): 93-102.

20. Daniel M, Szymański S, Černý V, Dusbábek F, Honzákowá E, Olejniĉek J. A comparison of developmental dynamics of Dermacentor reticulatus (Fabr.) of different geographic origins and their affection by different microclimate. Folia Parasitol. 1980; 27(1): 63-69.

21. Zygner W, Górski P, Wedrychowicz H. New localities of Dermacentor reticulatus tick (vector of Babesia canis canis) in central and eastern Poland. Pol J Vet Sci. 2008; 12(4): 549-555.

22. Daniel M, Černy V, Szymański S. A comparison of factors influencing the distribution of Dermacentor reticulatus (Ixodidae) in Czechoslovakia and Poland. Wiad Parazytol. 1986; 32(4-6): 355-361.

23. Szymański S. Distribution of the tick Dermacentor reticulatus (Fabricius, 1794)(Ixodidae) in Poland. Acta Parasit Pol. 1986; 31: 143-154.

24. Szymański S. The seasonal dynamics of the numbers of larvae in Dermacentor reticulatus (Fabricius, 1794) of the environs of Czerwone Bagno (Red Marsh). Wiad Parazytol. 1974; 20: 725-728 (in Polish).

25. Welc-Falęciak R, Bajer A, Behnke JM, Siński E. The ecology of Bartonella spp. infections in two rodent communities in the Mazury Lake District region of Poland. Parasitology. 2010; 137(7): 1069-1077.

26. Silaghi C, Woll D, Hamel D, Pfister K, Mahling M, Pfeffer M.Babesia spp. and Anaplasma phagocytophilum in questing ticks, ticks parasitizing rodents and the parasitized rodents - analyzing the host-pathogenvector interface in a metropolitan area. Parasit Vectors. 2012; 5: 191.

27. Stanko M. Striped field mouse (Apodemus agrarius, Rodentia) in Slovakia.Equlibria, 2014 (in Slovak).

28. Kadulski S. Ectoparasites of Polish arthrodactylous game animals. Acta Parasitol Pol. 1975; 23: 493-535.

29. Jaenson TG, Talleklint L, Lundqvist L, Olsen B, Chirico J, Mejlon H. Geographical distribution, host associations, and vector roles of ticks (Acari: Ixodidae, Argasidae) in Sweden. J Med Entomol. 1994; 31(2): $240-256$.

30. Jahfari S, Fonville M, Hengeveld P, Reusken C, Scholte EJ, Takken W, Heyman P, Medlock JM, Heylen D, Kleve J, Sprong H. Prevalence of Neoehrlichia mikurensis in ticks and rodents from North-west Europe. Parasit Vectors. 2012; 5: 74 .

31. Geist V. Deer of the World: Their Evolution, Behaviour, and Ecology. Pennsylvania: Stackpole Books, 1998.

32. Schley L, Roper TJ. Diet of wild boar Sus scrofa in Western Europe, with particular reference to consumption of agricultural crops. Mammal Rev. 2003; 33(1): 43-56.

33. Gebert C, Verheyden-Tixier H. Variations of diet composition of red deer (Cervus elaphus L.) in Europe. Mammal Rev. 2001; 31(3-4): 189-201.

34. Černy V, Daniel M., Korenberg E. Ixodes ricinus (L.) ticks on industrial tailings in north-west Bohemia. Med Parazitol. 1988; 2: 78-82.

35. Siuda K, Buczek A, Solarz K, Deryło A, Sadowski T, Kwiatkowski S, Horak B, Procyk A. Preliminary studies on the occurrence of Ixodes ricinus (Linnaeus, 1758) (Acari: Ixodida: Ixodidae) in the areas of Jura Krakowsko-Częstochowska characterised by varied degrees of anthropopressure-induced changes. Wiad Parazytol. 1991; 37: 17-20(in Polish).

36. Buczek A, Ciura D, Bartosik K, Zając Z, Kulisz J. Threat of attacks of Ixodes ricinus ticks (Ixodida: Ixodidae) and Lyme borreliosis within urban heat islands in south-western Poland. Parasit Vectors. 2014; 7: 562 .

37. Alekseev AN, Dubinina HV. Some aspects of mite (Oppiidae) and tick (Ixodidae) pathology as a result of anthropogenic pressure. In: Mitchell R, Horn DJ, Needham GR, Welbourn WC, editors. Acarology IX, Vol. 1.The Ohio Biological Survey, 1996 p. 117-120.

38. Buczek A. Anomalies in Argas (Argas) reflexus (Fabricius, 1794) (Acari: Argasidae). In: Mitchell R, Horn DJ, Needham GR, Welbourn WC, editors. Acarology IX, Vol. 1.The Ohio Biological Survey, 1996 p. 709-711.

39. Széll Z, Sréter-Lancz Z, Márialigeti K, Sréter T. Temporal distribution of Ixodes ricinus, Dermacentor reticulatus and Haemaphysalis concinna in Hungary. Vet Parasitol. 2006; 141(3-4): 377-379.

40. Gray JS, Dautel H, Estrada-Peña A, Kahl O, Lindgren E. Effects of climate change on ticks and tick-borne diseases in Europe. Interdiscip Perspect Infect Dis. 2009; 593232: 1-12.

41. Nowak M. Discovery of Dermacentor reticulatus (Acari: Amblyommidae) populations in the Lubuskie Province (Western Poland). Exp Appl Acarol. 2011; 54(2): 191-197.

42. Dautel H, Dippel C, Kämmer D, Werkhausen A, Kahl O. Winter activity of Ixodes ricinus in a Berlin forest. Int J Med Microbiol. 2008; 298(S1): 50-54. 